\title{
Increase Battery Time by Improvement in Regenerative Braking with Storage System in Hybrid Vehicle
}

\author{
Rao M. Asif ${ }^{1}$, Adnan Yousaf. ${ }^{1}$, Ateeq Ur Rehman ${ }^{2}$, Noman Shabbir ${ }^{3}$ and M. Tariq Sadiq ${ }^{4}$ \\ ${ }^{1}$ Faculty of Electrical Engineering, The Superior College (University Campus), Lahore, Pakistan \\ ${ }^{2,3}$ Department of Electrical Engineering, Government College University, Lahore, Pakistan \\ ${ }^{2}$ College of Internet of Things Engineering, Hohai University, Changzhou 213022, China \\ ${ }^{3}$ Department of Electrical Power Engineering \& Mechatronics, Tallinn University of Technology, Estonia \\ ${ }^{4}$ Department of Electrical Engineering, The University of Lahore, Lahore, Pakistan \\ Corresponding Author: ateeq.rehman@gcu.edu.pk
}

\begin{abstract}
Hybrid Electric Vehicle (HEV) is the most advance technology in automobile industries but long drive range in HEV is still a problem due to limited battery life. Regenerative braking system used in HEV to give backup power in deceleration mode which not only make HEV to drive longer but also increase the battery life cycle by charging of ultra-capacitor. Many researches have been done for increase the life cycle of battery by improvement in regenerative braking system where regenerated energy not fully returned to battery due to power losses are experienced in between such as losses in the motor armature and switching. In proposed system, improved regenerative braking system introduced which is simple, efficient due to less power losses in between BLDC motor and ESS without using of buck or boost system to minimized the losses. In regenerative braking mode, energy can be boosted by using of motor induction in winding by using H-bridge switches technic in inverter and transfer energy to ESS with minimum losses. These switches controlled by PWM through fuzzy logic controller. In resultant, battery working time and life will improve.
\end{abstract}

Index Terms - Hybrid Electric vehicle, Energy Storage System, Regenerative Braking System

Date Received 30 May 2019

Date Accepted 25 June 2019

Date Published 5 July 2019

\section{INTRODUCTION}

$\mathrm{V}$ EHICLE becomes one of the necessary things in this advance world to make travel ease. So the uses of vehicle increased rapidly [1]. Fossil fuels are the main resources of world, increase in using the fossil fuel is the serious environmental concern and reserve of fossil fuel is reducing day by day [2]. To reduce the environmental pollution, electric vehicle introduced. As the electric vehicle does not require the fuel oil so that technology has reduced the pollution level [3]. From last years, electric vehicles are becoming more popular due to improvement in performance and zero carbon emission. Electrical vehicle is totally environmental friendly. Lead acid batteries are mostly used in EVs due to its economic benefit and efficiency. But low range is still problem in electric vehicle due to limited battery storage capacity [4] [5]. For increasing of battery life, two methods are widely used in HEV; one is with fuzzy logic based battery management strategy and second is through improvement in regenerative braking system. Many researches have been done on improvement in battery life with different methods lets have looked on some previous researches. In 2009 Zhang Jing Ming introduced a fuzzy logic based regenerative braking system.in this system battery pack work with IC engine to reduce the use of oil. SOC of battery is controlled by FLC to keep the charging and discharging of battery stable. This improves the battery life [6]. In $2015 \mathrm{Xu}$ jiaqun, Cui Haotian was introduced a regenerative braking for BLDC motor in light electric vehicle. Single switch strategy used here to boost the EMF of motor. Regenerative system is consisting on half bridge 3 phase source converter, microcontroller, brake signal input, hall signal input, bus current sensor BLDC motor and Lead acid battery pack [7]. In 2016 Farshid Naseri introduced effective regenerative braking system which consists on battery/ super capacitor and BLDC motor. By using switching technic, D.C link voltage boosted here for transfer power to super capacitor and battery through inverter [8]. In 2016 Akhila $M$ and Prof. Patnan P introduced regenerative braking system which based on fuzzy interference system. This method offered 50\% more distance travelled by HEV. Rotor position is verified by Hall sensor and FLC control the switching of MOSFET according to rotor position [9]. In 2016 N.Pothirasan and Dr. M.Pallikonda introduced regenerative system by using BLDC motor for EV. Hall Effect sensor is used for proximity switching positioning speed detection and sensing current application. Three Hall Effect sensors used in BLDC motor which are connected to Arduino Uno board. 
Motor forward reverse position is controlled by PWM [10]. In 2016 O. C. Kivanc, O. Ustun, G. Tosun and R. N. Tuncay introduced regenerative braking system in which electric motor inverter use as boost converter. Hall sensor used here to get proper braking interval. Inductance of stator winding is act as a storing device to complete the boosting operation by using switching technic [11]. In all methods, regenerative braking is effective to give power to battery/ capacitor in acceleration mode. But proper braking will be effective when all generative power will capture by battery/capacitor with minimum losses. Battery consumes maximum power during acceleration mode and ultracapacitor assist in this time by providing power. If battery and capacitor charge properly in regenerative mode, then life time of battery will improve. By using this offered work overall traveling time of vehicle will improve due to increase in battery life cycle.

\section{LITERATURE REVIEW}

Hybrid electric vehicle is the upcoming leading vehicle technology in all over the world. Electric vehicle has not only reduced the pollution level but also decrease the use of fusel fuel oil [12]. In electric vehicle, long drive range was problem but hybrid electric vehicle has solved this problem by hybrid technology [13]. When two energy sources in vehicle work together then it is called HEV. Main source of hybrid electric vehicle is battery power. Super-capacitor or Ultra-capacitor used to assist the battery power in acceleration mode of vehicle when more power required [14].

\section{A. Conventional Hybrid Vehicle}

Today in Latin America, market of hybrid vehicle has been increased. Long distance and increasing fuel prices are the important factor for people to purchase such kind of vehicle. In previous researches, Optimization of ICE was implemented in steady state for hybrid electric vehicle. This is not considered to the complete powertrain. In 2006 Wany Feng, Zhang Tong introduced control strategy for getting efficiency from full powertrain of hybrid vehicle which minimized the fuel consumption in operation point of vehicle. This not only efficiency of internal combustion engine but also increase efficiency of overall powertrain. [15]. In 2014 Shane Overington introduced model of internal combustion engine which based on operating speed and torque for designing new control strategy in power system and hybrid electric vehicle to optimized the engine efficiency and performance. The developed proposed model such that its only utilized limited number of operating condition in ICE [16]. In 2016 E. Femandez, F Augeri introduced system where increase the range of electric mode of vehicle by adding extra batteries. First mode of vehicle is electric mode in which vehicle drive only on battery power second mode of vehicle is the combine mode where IC engine and battery power combine work for reduce the fuel consumption and this mode need when more speed is required. And third mode is only IC engine when battery powers finish then this mode of vehicle active and IC engine use fuel only. After test drive it was observed that the best performance of vehicle is obtained when it runs of combine mode, mean battery power and IC engine run combined [17].

TABLE I

COMPARISON OF CONVENTIONAL ELECTRICAL VEHICLE

\begin{tabular}{|l|l|l|l|}
\hline $\begin{array}{l}\text { Yea } \\
\text { r }\end{array}$ & Method & Parts & Benefit \\
\hline 2006 & $\begin{array}{l}\text { Control } \\
\text { Strategy }\end{array}$ & $\begin{array}{l}\text { Battery, IC } \\
\text { engine, } \\
\text { Motor }\end{array}$ & $\begin{array}{l}\text { Reduced the usage of fuel by } \\
\text { using of battery power }\end{array}$ \\
\hline 2014 & $\begin{array}{l}\text { Torque and } \\
\text { speed based } \\
\text { control } \\
\text { strategy }\end{array}$ & $\begin{array}{l}\text { ICE, } \\
\text { battery, } \\
\text { motor }\end{array}$ & $\begin{array}{l}\text { optimize the engine efficiency } \\
\text { to reduce the fuel consumption }\end{array}$ \\
\hline 2016 & $\begin{array}{l}\text { Adding extra } \\
\text { batteries }\end{array}$ & $\begin{array}{l}\text { ICE, } \\
\text { batteries, } \\
\text { motor }\end{array}$ & $\begin{array}{l}\text { In first mode battery used in } 2^{\text {nd }} \\
\text { mode battery and ICE used in } \\
3^{\text {rd }} \text { ICE used when battery } \\
\text { power finish. }\end{array}$ \\
\hline
\end{tabular}

\section{B. Fuel Cell Hybrid Electric Vehicle}

Fuel cell hybrid vehicle have ability to reduce dependence on oil and decrease harmful emission that help to climate change. In fuel cell study, one of the key technologies is energy management strategy. Main targets of energy management strategy are maximum recovery of braking energy, reducing the load of fuel cell engine and optimizing the area of working [18]. These tasks can be achieved by real time power distribution of fuel cell and output of auxiliary energy. In order to solve these problems an additional auxiliary power is required to provide supported power when vehicle need acceleration. In 2012 Duo Xiao, Qiuting Wang introduced energy management strategy for fuel cell based HEV. In proposal, power system of FCHEV is multi energy power train system, which consists on battery, fuel cell, DC/DC converters, motor and other components. We can get good fuel efficiency and better performance of vehicle power. All strategy is based on fuzzy logic controller. The main work of FLC is maintaining the suitable membership equation for all input and output parameters [19]. In FCHEV, two energy sources provide supply to power train to fulfil load demand. Fuel cell is the primary source and battery is the secondary source. Sometime Supercapacitor also used as power reversible source [20]. Sizing of power train components can be achieved by optimal power management strategy. Most fuel cell operating point goes to higher efficiency range by adding energy storage system. In 2014 Rafika Dinnawi, Dima Fares, Riad Chedid, presented an optimized energy management solution of optimization problem with 
task to minimize consumption of hydrogen in FCHV to achieve split of power between source. Optimization goal is to minimize the hydrogen consumption and reduce operational cost [21]. Nowadays FCHEV and HEV are considered an environmental friendly due to increasing energy crisis and pollution problems [22]. Researchers are working in this field to make the better energy management strategy for HEV's. Many control strategies were proposed in this field [23]. These control strategies divided into two groups. One is online control strategies and second is offline control strategies. Online control strategies are based on neural network control, predictive control or fuzzy logic control. Offline control strategies are based on pre-defined cost function such as equivalent consumption minimization strategy or pontryagin minimum principle, dynamic programming. In real time application, it is difficult to know a prior in the global optimization control for overall driving cycle [24]. That is why, the global optimization control is normally offline implemented. This is highly dependent on future driving information. In 2017 Daming Zhou, Fei Gao, Alexandre Ravey and Ahmed Al-Durra introduced online energy management strategy which based on prediction and can be used for online driving cycle [25].

TABLE II

COMPARISON OF FUEL CELL HYBRID ELECTRIC VEHICLE

\begin{tabular}{|c|c|c|c|}
\hline Year & Method & Parts & Benefit \\
\hline $\begin{array}{l}2012 \\
{[19]}\end{array}$ & \begin{tabular}{l}
\multicolumn{1}{c}{ Energy } \\
management \\
strategy for \\
recovery max \\
braking energy
\end{tabular} & $\begin{array}{l}\text { FC, battery, } \\
\text { motor, DC/DC } \\
\text { converter }\end{array}$ & $\begin{array}{l}\text { This strategy is } \\
\text { control with FLC which } \\
\text { drive vehicle in four } \\
\text { different modes by } \\
\text { combination of battery } \\
\text { and FC power and } \\
\text { Regenerative braking } \\
\text { power used to charge } \\
\text { the battery. Which help } \\
\text { to increase the driving } \\
\text { timing of vehicle. }\end{array}$ \\
\hline $\begin{array}{l}2014 \\
{[21]}\end{array}$ & $\begin{array}{l}\text { Optimization of } \\
\text { energy } \\
\text { management for } \\
\text { minimize energy } \\
\text { consumption in } \\
\text { FCHEV }\end{array}$ & $\begin{array}{l}\text { FC, battery, } \\
\text { regenerative } \\
\text { braking, } \\
\text { motor, }\end{array}$ & $\begin{array}{l}\text { Source power split } \\
\text { and divided into two } \\
\text { modes charge and } \\
\text { discharge mode which } \\
\text { minimized the power } \\
\text { consumption of FC and } \\
\text { also reduce the } \\
\text { operational cost. }\end{array}$ \\
\hline $\begin{array}{r}2017 \\
{[25]}\end{array}$ & \begin{tabular}{l}
\multicolumn{2}{c}{ Prediction } \\
based online \\
energy \\
management \\
strategy which \\
consist r on \\
(NARNN)
\end{tabular} & $\begin{array}{l}\text { Battery, FC, } \\
\text { motor, } \\
\text { regenerative } \\
\text { braking, neural } \\
\text { network } \\
\text { controller }\end{array}$ & $\begin{array}{l}\text { By using this strategy, } \\
\text { NARNN can work } \\
\text { efficiently and on every } \\
\text { moving window step, } \\
\text { used newly measured } \\
\text { online driving cycle. } \\
\text { Which help to tell } \\
\text { prediction based } \\
\text { accurate driving cycle to } \\
\text { reduce the energy } \\
\text { consumption of vehicle. }\end{array}$ \\
\hline
\end{tabular}

\section{Hybrid Electric Vehicle}

Road transport is the main cause of pollution in UK [26]. Using of EV could reduction of carbon emission. Hybridize the electric vehicle with adding Supercapacitor with battery is the possible solution. Supercapacitor work as part of hybrid electric system which can provide rapid high power during acceleration of vehicle even when the battery is decreased the power due to low state of charge. One more benefit of Supercapacitor is that it can protect the battery from high peak of current which can damage the batteries [27]. Supercapacitor can extend the life of battery by assisting during peak requirement of power. Therefore, overall efficiency of vehicle increases and also increases the driving range. HEV is still facing less driving time problem due to limited time of battery. In 2012 Rebecca carter introduced system which consists on energy storage system, Supercapacitor and battery pack in HEV. Battery packs assist to battery power in energy requirement when vehicle is on acceleration mode. Battery supply power on constant speed in acceleration mode. Battery connected in parallel with Supercapacitor and can store the energy of regenerative braking which improved the life cycle of battery [28]. In 2015 K. B. Adam and M. Ashari introduced system in which, improvement in battery life and charging and discharging current was adjusted by the bidirectional converter. This converter regulates the current to prevent battery damage and also decrease the gassing phenomena in battery. Bidirectional converter changes the voltage according to the set point and gets the charge and discharge results from DC link voltage. In simulation result it is shown that the bidirectional converter efficiency is $90 \%$ and can regulate the charging and discharging current and maintain the output voltage [29]. In 2016 the attention of researcher Anupama Singh, Dr. P.B.Karandikar was make a battery management system to overcome the improper charging and discharging of battery. For this purpose, ultra-capacitor connected with the lead acid battery with intelligent controller system. State of charge (SOC) depth of charge (DOC) are also analyzed. For performance checking of this method, comparing the results of current voltage and temperature with different modes like only with battery or ultracapacitor with battery or fuzzy controller with battery and ultracapacitor battery with fuzzy controller [30].

TABLE III

DETAIL TECHNOLOGY USED IN HYBRID ELECTRICAL VEHICLE

\begin{tabular}{|c|c|c|c|}
\hline Year & Method & Parts & Benefit \\
\hline $\begin{array}{r}2012 \\
{[28]}\end{array}$ & $\begin{array}{c}\text { Energy } \\
\text { Storage system }\end{array}$ & $\begin{array}{l}\text { Battery, } \\
\text { Supercapacitor, } \\
\text { regenerative } \\
\text { braking }\end{array}$ & $\begin{array}{l}\text { Improve the } \\
\text { driving time of } \\
\text { vehicle also increase } \\
\text { life time of battery }\end{array}$ \\
\hline $\begin{array}{r}2015 \\
{[29]}\end{array}$ & \begin{tabular}{l}
\multicolumn{2}{c}{ Adjusting } \\
current through \\
Bidirectional \\
converter
\end{tabular} & $\begin{array}{l}\text { Battery, } \\
\text { Supercapacitor, } \\
\text { bidirectional } \\
\text { converter, fuzzy } \\
\text { logic controller }\end{array}$ & $\begin{array}{l}\text { Controlling the } \\
\text { current of battery } \\
\text { from over charge and } \\
\text { discharge } \\
\text { bidirectional } \\
\text { converter which } \\
\text { control by fuzzy logic } \\
\text { controller. This will } \\
\text { help to improve } \\
\text { vehicle driving time }\end{array}$ \\
\hline $\begin{array}{l}2016 \\
{[30]}\end{array}$ & \begin{tabular}{l}
\multicolumn{1}{c}{ Battery } \\
management \\
system
\end{tabular} & $\begin{array}{l}\text { Lead acid } \\
\text { battery, } \\
\text { Ultracapacitor, }\end{array}$ & \begin{tabular}{lr}
\multicolumn{2}{c}{ Control the battery } \\
charging and \\
discharging current
\end{tabular} \\
\hline
\end{tabular}




\begin{tabular}{|l|l|l|l|}
\hline & $\begin{array}{l}\text { fuzzy logic } \\
\text { controller }\end{array}$ & $\begin{array}{l}\text { through fuzzy logic } \\
\text { controller with PWN } \\
\text { method to improve } \\
\text { battery timing. }\end{array}$ \\
\hline
\end{tabular}

\section{Plug in Hybrid Electric Vehicle}

In PHEV, the combination of lithium-ion battery with Ultracapacitor is seen as ideal approach. Using battery and Ultracapacitor based energy storage system has been already accepted widely in PHEV. Battery provides the constant average power to motor and Ultracapacitor provide the peak maximum power to motor. PHEV first consume the battery power and after discharge of batteries it behaves like an ICE based conventional vehicle [31]. Many researches have been done on extending the battery life and reduce the usage of fuel. In 2010 Lei Wang, Xiaohu Liu, Hui Li introduced energy management strategy to reduce the fuel consumption and increase the battery life in PHEV. In this system focus on SOC regulation of battery and Ultracapacitor and forecast the control of vehicle according to the driver command. This system was checked on real time digital simulation (RTDS). Following objectives were achieved by the proposed strategy. (1) Power sharing maintained between UC and battery. (2) SOC of UC was control by the receiving reference. (3) In advance, the response is according to the driver command [32]. In PHEV drive train is included on electric motor, battery, devices and internal combustion engine (ICE) to connection vehicle to utility grid. Most of the time vehicle use energy on battery as electric mode and when battery power is not sufficient then it covert to ICE mode [33]. In America some researchers focus to expansion of generation and which impact on distribution system [34]. In recently project in America in 2008, Schneider suggest that the utility grid not used at night time and the demand of PHEV should be shifted on night time by smart charging method to prevent $50 \%$ peak load for electric vehicle [35]. Regarding this problem Niklas Rotering in 2010 introduced solution of this problem is that first optimizes the energy flow and charging time of vehicle. It reduces the daily cost of electricity and also battery degradation will not increase. Second is if energy supply from different sources, such as solar or wind then it will be facilitated. Because shortfalls in production are cause to raise the price and therefore charging shifts to other time of the day. This will improve the economy of PHEV and reduce the usage of fossil fuel oil [36].

TABLE IV

IMPROVEMENT IS LISTED IN PLUGIN HYBRID ELECTRIC VEHICLE

\begin{tabular}{|c|l|l|l|}
\hline Year & \multicolumn{1}{|c|}{ Method } & \multicolumn{1}{|c|}{ Parts } & \multicolumn{1}{|c|}{ Benefit } \\
\hline 2010 & Energy & Battery, ultra \\
management & $\begin{array}{l}\text { Bacitor, forecast } \\
\text { control of vehicle, } \\
\text { ICE }\end{array}$ & $\begin{array}{l}\text { Bytrolling SOC of } \\
\text { battery improve the } \\
\text { battery time and save } \\
\text { the fuel in ICE. }\end{array}$ \\
\hline 2008 & \multirow{2}{*}{ strategy } & Battery, Motor, & $\begin{array}{l}\text { Change the timing of } \\
\text { charging from peak } \\
\text { hours to off peak } \\
\text { hours }\end{array}$ \\
\hline 2010 & Smart charging & Battery, Motor, & Reduced the using of \\
\hline
\end{tabular}

\begin{tabular}{|l|l|l|l|}
\hline [36] & & $\begin{array}{l}\text { Internal } \\
\text { combustion } \\
\text { engine }\end{array}$ & $\begin{array}{l}\text { electricity in peak } \\
\text { hours by using parallel } \\
\text { connecting sources, } \\
\text { like wind turbine, } \\
\text { solar panels etc. }\end{array}$ \\
\hline
\end{tabular}

\section{REgENERATIVE BRAKING SYSTEM REVIEW}

In hybrid electric vehicle, BLDC motor act as a generator during regenerative braking. Kinetic energy generates and capture by using proper switching technique is motor drive. This energy used to charge the battery and Ultracapacitor. Motor speed and input voltage is used as reference parameter to calculate the maximum current produced in BLDC motor during braking [37]. There are some control strategies that are discussed in detail below.

\section{A. Control Strategy for Regenerative Braking}

Control strategy in regenerative braking performs an important role for recovering energy and maintains the vehicle performance. Control and distribution strategy play and important role to achieving the goal of braking force. Different strategy has been developed, which divided into some types shown in table 5 .

TABLE V

EVALUATION OF CONTROL STRATEGY IN REGENERATIVE BRAKING SYSTEM

\begin{tabular}{|l|l|l|}
\hline Name & Method & Benefit \\
\hline $\begin{array}{l}\text { Jingang } \\
\text { Guo } \\
{[37]}\end{array}$ & $\begin{array}{l}\text { Distribute the generated current in } \\
\text { optimized way between battery } \\
\text { and SC according to SOC. }\end{array}$ & $\begin{array}{l}\text { Generated energy from } \\
\text { RGB effectively used by } \\
\text { batter and SC which } \\
\text { increase the life of } \\
\text { battery }\end{array}$ \\
\hline $\begin{array}{l}\text { Farshid } \\
\text { Naseri } \\
{[38]}\end{array}$ & $\begin{array}{l}\text { Provide boosted regenerative } \\
\text { energy from inverter by } \\
\text { appropriate switching strategy to } \\
\text { charge the ESS }\end{array}$ & $\begin{array}{l}\text { Increase the efficiency } \\
\text { of overall system, } \\
\text { increate the driving } \\
\text { range of vehicle } \\
\text { including with battery }\end{array}$ \\
\hline $\begin{array}{l}\text { O. C. } \\
\text { Kivanc, } \\
\text { O. }\end{array}$ & $\begin{array}{l}\text { BLDC stator winding help to store } \\
\text { generated EMF for some time and } \\
\text { then transfer to battery and SC } \\
\text { through Transistor control pattern } \\
\text { G. }\end{array}$ & $\begin{array}{l}\text { Regenerative braking } \\
\text { efficiency increase, } \\
\text { driving range of HEV } \\
\text { also increase. }\end{array}$ \\
\hline boosted power
\end{tabular}

\section{B. H-Bridge Switch Strategy for Regenerative System}

In 2011 Cheng-Hu Chenl, Wen-Chun Chi, and MingYang Cheng introduced single, two and three switches control strategy for regenerative braking in hybrid electric vehicle according to the different driving condition. For getting the dynamic regenerative and charging for different speed range, bidirectional DC/AC power converter used. When vehicle operated in regenerating mode, the dynamic energy transferred from vehicle to battery/capacitor AC to DC converter. Main concerned issue is the cost and efficiency and reliability when making hybrid electric vehicle [40]. In this regard, H-Bridge switching comparison in regenerative braking is shown in table VI.

TABLE VI

H-BRIDGE SWITCHING COMPARISON IN REGENERATIVE BRAKING

\begin{tabular}{|l|l|l|}
\hline Name & Method & Benefit \\
\hline
\end{tabular}




\begin{tabular}{|c|c|c|}
\hline $\begin{array}{l}\text { Cheng-Hu Chenl, } \\
\text { Wen-Chun Chi, } \\
\text { and } \\
\text { Ming-Yang Cheng } \\
\text { [41] }\end{array}$ & $\begin{array}{l}\text { One, two and three } \\
\text { switches strategy used } \\
\text { according to the } \\
\text { different driving } \\
\text { situation }\end{array}$ & $\begin{array}{l}\text { Get better regenerative } \\
\text { power in different speed } \\
\text { range. }\end{array}$ \\
\hline $\begin{array}{l}\text { Farshid Naseri } \\
\quad[38]\end{array}$ & $\begin{array}{l}\text { Regenerative power } \\
\text { boosted in motor along } \\
\text { with help of switching } \\
\text { technic. These } \\
\text { MOSFET's control } \\
\text { through PWM with } \\
\text { fuzzy logic controller. }\end{array}$ & $\begin{array}{l}\text { Increase efficiency of } \\
\text { regenerative braking, } \\
\text { cost of system also } \\
\text { reduced due to not using } \\
\text { extra converter circuits. }\end{array}$ \\
\hline $\begin{array}{l}\text { Andrew Adib and } \\
\text { Rached Dhaouadi } \\
\text { [42] }\end{array}$ & $\begin{array}{l}\text { H-bridge switching } \\
\text { technique used for } \\
\text { boosting regenerative } \\
\text { power with ESS }\end{array}$ & $\begin{array}{l}\text { Increase the driving } \\
\text { range with efficient } \\
\text { regenerative braking. } \\
\text { System is cost effective. }\end{array}$ \\
\hline
\end{tabular}

\section{INCREASE BATTERY TIMING BY USING SUPERCAPACITOR/ULTRACAPACITOR}

Ultracapacitor play a vital role in electric vehicle to increase the time of battery by providing assistive power to battery in acceleration mode. And during deceleration mode, drive produces high peak current to charge the battery but due to low charging current property it could not store in battery. Other hand supercapacitor can absorb this high peak current easily which are now a days using in traction drive system and also in grid connected system [43]. In LEV, battery combined work with supercapacitor based energy storage system for utilize all energy of regenerated braking system and control the discharge current of battery. Supercapacitor or ultracapacitor is well suited for HEV for its current handling properties of peak power load because of its long life, less losses and maintenance free if compare to battery [44]. In 2012 Rebecca Carter introduced control strategy where supercapacitor play rule to increase the life time of battery. In electric vehicle, Supercapacitor not only helps to reduced load in battery and extends battery life it also increase the efficiency of electric vehicle. In this paper, different kind of control strategies made with battery and supercapacitor for increasing battery life. An EV was made in catholic University of Chile by using lead acid battery which connected to supercapacitor packs and with single half bridge converter [45]. This strategy increased the efficiency by $12.7 \%$. Another Italian research center was made car with battery and supercapacitor. In this car, supercapacitor directly connected to battery in parallel. By avoiding converter losses, the efficiency increased to $11.1 \%$ [46].in this paper show that the hybridizing battery with supercapacitor in EV in the effective solution to reduce the peak current of battery and extend battery life. Two speed profiles define here which named as George Square profile and the ECE-15 profile.

Current reduction only can achieve by using supercapacitor [47]. In 2016 Kaspars Kroics introduced supercapacitor based energy storage system in hybrid electric vehicle. At the time of acceleration, the battery provides the constant current to motor. And in idle time current from battery is not taking to allow charging the supercapacitor for the next cycle of braking. For this reason, supercapacitor give positive and negative variation during this current and it indicate the required increase or decrease current through voltage [48]. In this control algorithm, converter controls the flow of battery current. In deceleration mode, braking mode active and supercapacitor capture all the regenerative energy and the supercapacitor energy is more useful is acceleration mode relatively to battery. This combined work of supercapacitor with battery power, increase the life time of battery [49]. In 2016 Anupama Singh and Dr. P.B Karandikar ultracapacitor in electric vehicle to improve the life cycle of lead acid battery. Battery takes major roles in hybrid electric vehicle for balancing the power. Conventional battery has many issues of electrification if compare to Li-ion batteries. So it is proved in this research that the lead acid battery can meet the efficiency of Li-ion battery in low cost.

For control the charging and discharging current of battery, pulse width modulation technique is used here which controlled by fuzzy logic controller. Fuzzy logic controller can check all the parameters (temperature, current, voltage etc.) which are already set in controller and then compare it to the actual receiving signals and generate the output control pulse signal to control the current of battery. Ultracapacitor power used to assist the battery power during acceleration mode of vehicle. Overall system can increase the life of lead acid battery and also reduced the cost of battery as well as size of battery also reduced [50].

$$
\text { TABLE VII }
$$

INCREASE BATTERY TIMING COMPARISON IN EV

\begin{tabular}{|c|c|c|c|}
\hline Name & Program & Method & Benefit \\
\hline $\begin{array}{l}\text { Rebecca } \\
\text { Carter } \\
{[47]}\end{array}$ & $\begin{array}{l}\text { Increase } \\
\text { battery time } \\
\text { in HEV }\end{array}$ & $\begin{array}{l}\text { Use hybridizing of } \\
\text { battery with } \\
\text { supercapacitor to } \\
\text { reduce the peak } \\
\text { current of battery }\end{array}$ & $\begin{array}{l}\text { Battery current } \\
\text { remain } \\
\text { constant in any } \\
\text { power demand } \\
\text { and life of } \\
\text { battery } \\
\text { increases }\end{array}$ \\
\hline $\begin{array}{l}\text { Kaspars } \\
\text { Kroics } \\
{[48]}\end{array}$ & $\begin{array}{l}\text { Increase } \\
\text { battery time } \\
\text { in HEV }\end{array}$ & $\begin{array}{l}\text { Control the flow of } \\
\text { current through } \\
\text { converter in battery } \\
\text { by using SOC and } \\
\text { supercapacitor assist } \\
\text { to battery in } \\
\text { acceleration mode }\end{array}$ & $\begin{array}{l}\text { Driving range } \\
\text { of vehicle } \\
\text { increase } \\
\text { along with } \\
\text { increasing the } \\
\text { battery time }\end{array}$ \\
\hline $\begin{array}{l}\text { Anupama } \\
\text { Singh \& Dr. } \\
\text { P.B } \\
\text { Karandikar } \\
{[50]}\end{array}$ & $\begin{array}{l}\text { Increase } \\
\text { battery time } \\
\text { in HEV }\end{array}$ & $\begin{array}{l}\text { Power of battery and } \\
\text { ultracapacitor } \\
\text { controlled by FLC } \\
\text { based intelligent } \\
\text { controller by using } \\
\text { PWM technic }\end{array}$ & $\begin{array}{l}\text { Cost and size } \\
\text { of battery } \\
\text { reduced as } \\
\text { well as life of } \\
\text { battery also } \\
\text { increase }\end{array}$ \\
\hline
\end{tabular}




\section{INCREASE BATTERY TIMING BY USING USING REGENERATIVE BRAKING SYSTEM}

Regenerative braking is the best way to increase the battery timing in hybrid electric vehicle. It also increases the life of battery and also improves the overall efficiency and range of vehicle. In 2016 Farshid Naseri introduced effective regenerative braking system which consists on battery/ super capacitor and BLDC motor. Battery and supercapacitor is using as HESS in HEV. The Advantages of HESS has many advantages like supercapacitor is used for effective harness the kinetic energy due to high power density, supercapacitor assist to power of battery in peak load and increase the battery life, driving range also increase due to effectively saved energy. In past researches, different configurations of HESS introduced but the battery and supercapacitor based HSEE is most reliable [51-52].

In this system battery is directly connected to the DC bus and DC/DC converter used to manage the power flow between the supercapacitor and battery. For this purpose, two separates ESS are required which was cost effective. For overcome this deficiency the present work is offered. By using switching technic, D.C link voltage boosted here for transfer power to super capacitor and battery through inverter. Battery pack directly connected to D.C link with diode in series. Supercapacitor is connected in parallel with battery pack through buck converter. Battery pack is supply to BLDC motor in normal condition. During the acceleration time, super capacitor assists to battery power through buck converter. In this method the regenerative braking is improved by $20 \%$ if compare to previous method and EV driving range increase about 5 cycle and also increase the life of battery [53]. In 2017 Andrew Abid, Rached Dhaouadi introduced modeling and analysis of regenerative braking with ESS. In regenerative mode of vehicle, when motor work as generator and producing energy then by applying the proper switching the energy can be captured. This energy used to charge the battery and supercapacitor [54]. It should have clear idea of generated and harvesting energy in HESS for understanding of system. In this introduced work the calculation is confirmed by the results of experiments of DC motor and regenerative braking. In general topology of the regenerative braking is where mechanical load is coupled with BLDC motor which works as generator in deceleration mode. BLDC motor produced energy and supplied to supercapacitor and battery through inverter. Supercapacitor used as auxiliary power source which connect to DC link through bi-directional DC/DC converter to het the optimal charge and discharge operation. Supercapacitor work as assistive power in acceleration mode and harvest the energy is regenerative mode. H-bridge circuit is use to control the rotation of motor. The generated energy can be harvested by supercapacitor through applying the proper switching scheme in H-bridge circuit. Motor itself inductance along with the $\mathrm{H}$-bridge switches used as a boost converter which boost the generated back EMF which force the current flow in reverse in direction and back flow to the supercapacitor [55].

TABLE VIII

COMPARISON OF REGENERATIVE BRAKING WHICH USED TO INCREASE BATTERY TIMING

\begin{tabular}{|c|c|c|}
\hline Name & Method & Benefit \\
\hline $\begin{array}{lr}\text { In } & 2016 \\
\text { Akhila } \mathrm{M} \\
\text { and Prof. } \\
\text { Patnan P } \\
\text { [51] }\end{array}$ & $\begin{array}{l}\text { Appropriate switching } \\
\text { technic use in BLDC } \\
\text { drive to boost the } \\
\text { generated power and } \\
\text { charge the HESS (battery } \\
\text { and supercapacitor) }\end{array}$ & $\begin{array}{l}\text { Supercapacitor charge } \\
\text { rapidly by boosted power } \\
\text { and assist to battery which } \\
\text { increase the life of battery }\end{array}$ \\
\hline $\begin{array}{c}\text { Farshid } \\
\text { Naseri } \\
{[53]}\end{array}$ & $\begin{array}{l}\text { Inductance of BLDC } \\
\text { motor use at boosted } \\
\text { EMF and transfer to } \\
\text { HESS through switching } \\
\text { technic of inverter }\end{array}$ & \begin{tabular}{l}
\multicolumn{2}{c}{$20 \%$ regenerative } \\
braking improved if \\
compare to previous \\
technic. Life cycle of \\
battery also increase
\end{tabular} \\
\hline $\begin{array}{l}\text { Andrew } \\
\text { Abid, } \\
\text { Rached } \\
\text { Dhaouadi } \\
{[54]}\end{array}$ & $\begin{array}{l}\text { H-bridge switching } \\
\text { technic can boost the } \\
\text { motor EMF and charge } \\
\text { the battery and } \\
\text { supercapacitor }\end{array}$ & $\begin{array}{l}\text { Vehicle driving cycle } \\
\text { improve with increase the } \\
\text { battery timing. Cost of } \\
\text { vehicle is also reduced. }\end{array}$ \\
\hline
\end{tabular}

\section{Hybrid ENERGy STORAGE SySTEM}

Using of energy storage system in hybrid electric vehicle is very effective. It has many advantages such as battery safety, effective regenerative braking and improve acceleration in vehicle. Batteries and Ultra-capacitor is the main parts of ESS in HEV. In this contest a brief analysis is shown in Table IX.

TABLE IX

DIFFERENT SUPER-CAPACITOR AND BATTERY BASED ENERGY STORAGE SYSTEM

\begin{tabular}{|l|l|l|}
\hline Name & Method & Benefit \\
\hline $\begin{array}{l}\text { Tingyou Ming, } \\
\text { Jeiwen Deng, } \\
\begin{array}{l}\text { Qiao Zhang } \\
\text { [57] }\end{array}\end{array}$ & $\begin{array}{l}\text { Supercapacitor and battery } \\
\text { based HESS used with double } \\
\text { layer EMS. Energy layer is for } \\
\text { SOC of SC and power layer } \\
\text { determine power split ratio } \\
\text { between SC and battery }\end{array}$ & $\begin{array}{l}\text { Increase efficiency } \\
\text { of RGB and } \\
\text { reduced peak } \\
\text { current for battery. } \\
\text { Battery life also } \\
\text { improve }\end{array}$ \\
\hline $\begin{array}{l}\text { Kaspars Kroics, } \\
\text { Viesturs Brazis } \\
\text { [58] }\end{array}$ & $\begin{array}{l}\text { Supercapacitor with DC/DC } \\
\text { converter is used as Retrofit } \\
\text { Kit which connected parallel } \\
\text { with battery to work as HESS }\end{array}$ & $\begin{array}{l}\text { Increase the life } \\
\text { time of battery and } \\
\text { also improve the } \\
\text { regenerative } \\
\text { braking energy } \\
\text { capturing }\end{array}$ \\
\hline $\begin{array}{l}\text { Parisa } \\
\text { Golchoubian and } \\
\text { Nassar L. Azad } \\
\text { [59] }\end{array}$ & $\begin{array}{l}\text { Real time non-linear model } \\
\text { predictive control used for a } \\
\text { battery supercapacitor based } \\
\text { hybrid energy storage system. }\end{array}$ & $\begin{array}{l}\text { Less losses, low } \\
\text { cost, increase } \\
\text { battery life }\end{array}$ \\
\hline
\end{tabular}

\section{METHODOLOGY \& SIMULATION RESUlTS}

In proposed method, the losses in electric storage system are reduced by using of switching strategy and neglecting of buck boost circuits in system which creates losses during 
conversion. This model is also cost effective due to neglecting of extra electronics circuit which consist of on hall effect based BLDC motor, 6 step inverter (H-bridge switching technique), fuzzy logic controller, MOSFET switches for energy storage system, battery and ultracapacitor.

\section{A. Regenerative Braking System}

In regenerative mode the bottom switches $\mathrm{S} 2, \mathrm{~S} 4$ and $\mathrm{S} 6$ are switched $\mathrm{ON}$ according to the gate pulses which generated from the fuzzy logic controller. Hall Effect sensor are used to obtain the proper braking cycle. Generated EMF from two phase of motor is transfer in switches S2 and S4 where S4 switch $\mathrm{ON}$ and $\mathrm{S} 2$ is OFF current transfer from $\mathrm{S} 4$ and then flow from diode of S2 this position maintains for a while and boosted the voltage at DC bus ultimately boost the power. After that this boosted power transfer to HESS through diodes of $\mathrm{S} 1$ and $\mathrm{S} 4$. Both switch $\mathrm{S} 1$ and $\mathrm{S} 4$ will remain OFF in this interval. There is no need of any boosted circuit which help to reduced losses. Stator winding of motor is act like a storage device to complete the boost function. So there is high inductance BLDC motor is better choice for effective regenerative system. Only two phase of motor can have produced energy in one time and rest one phase is idol. Fuzzy logic is control all the switches in same time as shown in figure.1. After completing this process, results of regenerative braking system shown in figure. 2 where inrush current of stator winding with generated EMF in motor during regenerative braking is shown. As above mentioned scenario, there should be boost in voltage that is shown in figure. 3 .

\section{A. Hybrid Electric Energy Storage System}

Energy of ESS is manage and controlled through three MOSFET switches Q1, Q2 and Q3. Technically specification can be seen in Table. Battery SOC is use to provide inputs to fuzzy logic controller for control the charging and discharging current. Overcharging and discharging can cause of reduced battery life. To make the battery current constant in discharging mode, switch Q2 provide controlled current at DC bus. Switch is controlled by the PWM through fuzzy logic controller. In charging mode of battery during regenerative mode of vehicle, Q1 work and provide charging current to battery. This proposed strategy helps to prevent the battery from degradation and life of battery increase. Same as ultra-capacitor is ready to absorb power of regenerative system in deceleration mode and there is only one switch Q3 work during discharging of capacitor is acceleration mode when load require high power from battery. Q3 switch provide controlled power to DC bus to make the stable voltage on DC bus. Three switches from through the rule based fuzzy logic controller. State of charge, current and voltage of battery and ultracapacitor during driving is shown in figure.4 and figure.5. To increase battery life charging current should always be there, it can see in figure.4. Whenever SOC is reduced then current and voltage will also be reduced, this is shown in figure.5.
SPECIFICATION OF HESS

\begin{tabular}{|c|c|}
\hline Characteristics & Specifications \\
\hline Battery Type & Lead Acid \\
\hline Battery Voltage & 24 Volt \\
\hline Battery current $\mathrm{Ah}$ & 100Ah \\
\hline Ultracapacitor voltage & $400 \mathrm{~V}$ \\
\hline Ultracapacitor rating & $1500 \mathrm{MF}$ \\
\hline
\end{tabular}

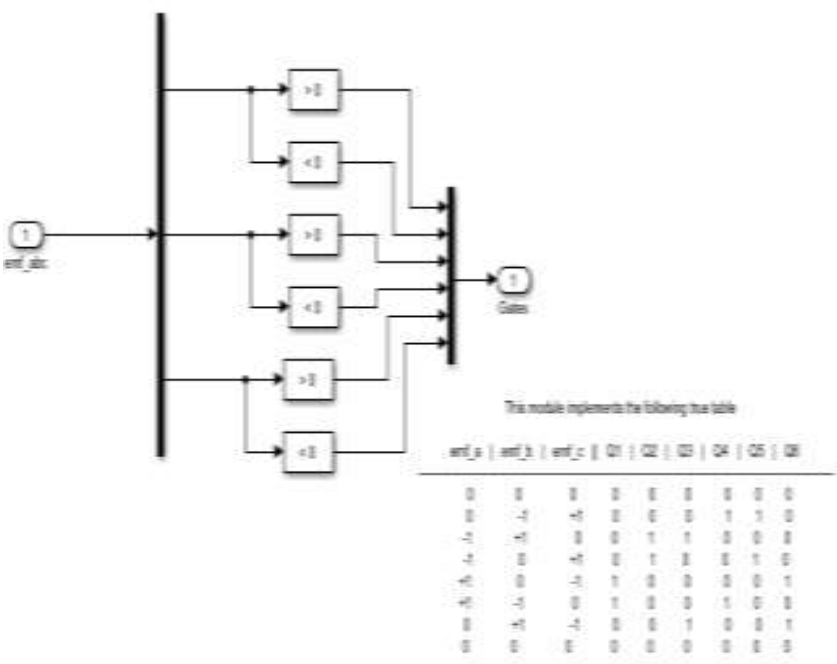

Fig 1. Gates inputs generated from fuzzy logic controller

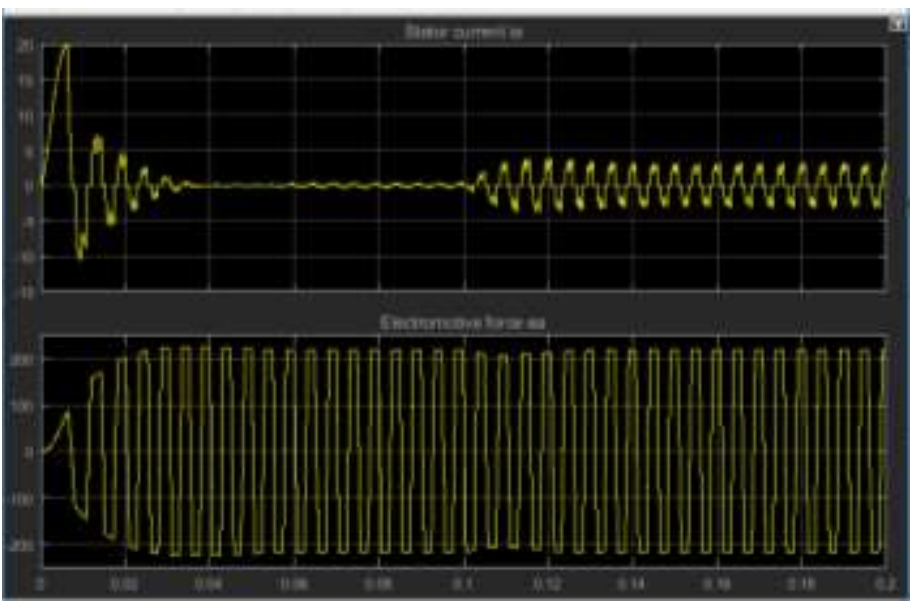

Fig 2 Inrush current \& Generated EMF in motor during regenerative braking 


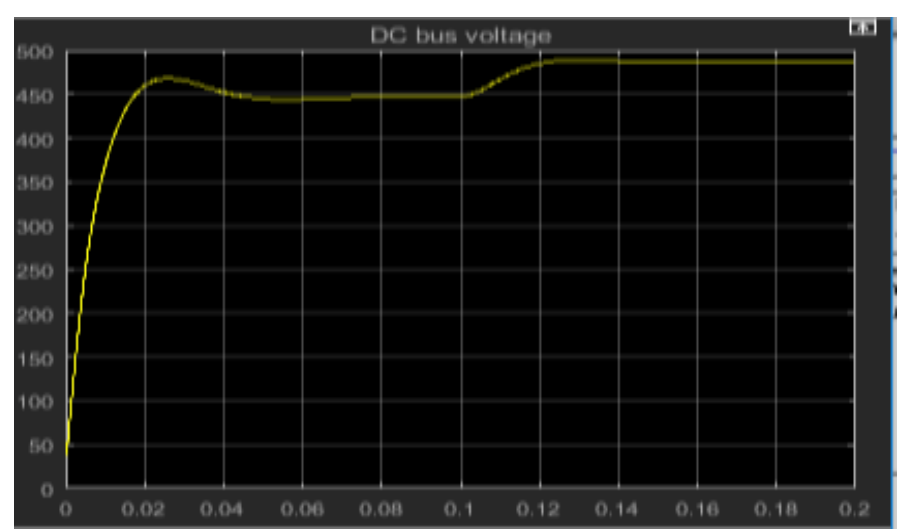

Figure. 3 Boosted voltages at DC bus

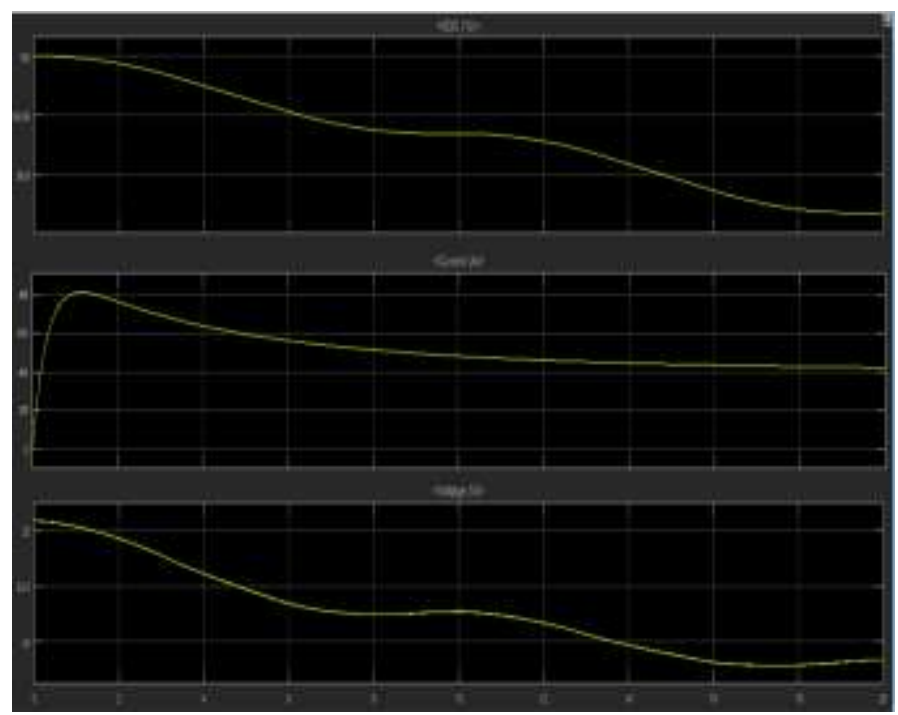

Figure 4. Discharging state of Battery during driving

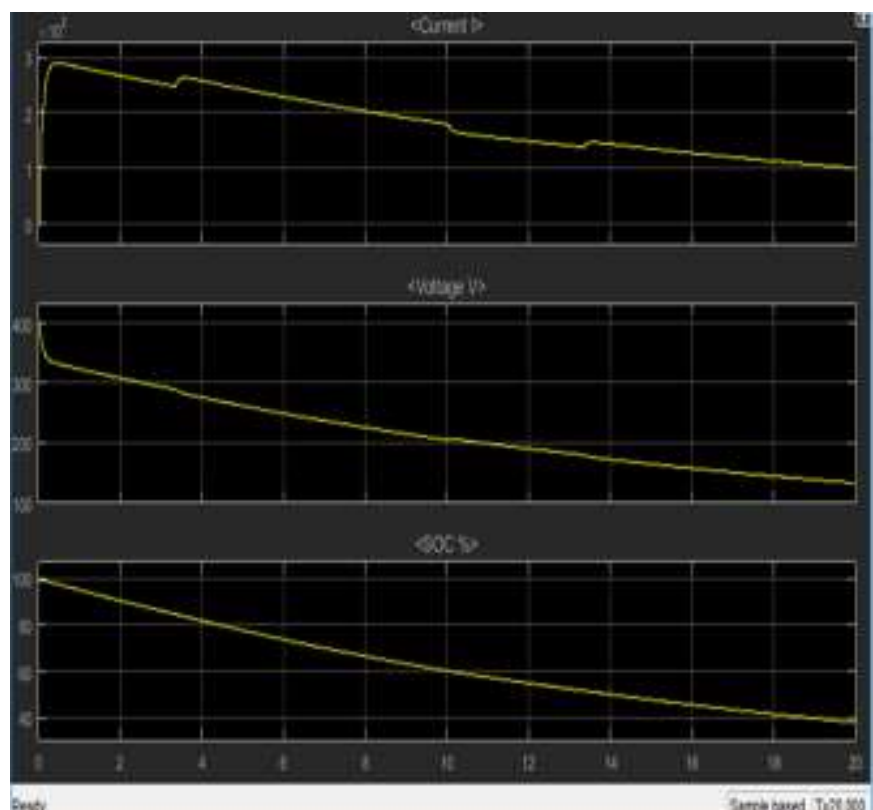

Figure.5. Discharging state of ultra-capacitor during driving

\section{CONCLUSION}

Results shows that the boosted power can be achieve without the buck boost converter which create losses in regenerative power. By the using of the $\mathrm{H}$-bridge switching technic, the motor back EMF collected and holding for a while and boosted power generated in switches. Boosted power divided into two parts one for charging of battery and other for ultra-capacitor. By feeding constant charging current to battery, battery charge on the constant load which is controlled form rule based fuzzy logic controller by getting input from the SOC of battery. Required voltages provided to the battery for charging with very less losses and battery charge minimum time. Same as in acceleration mode of vehicle, battery provide constant load to motor drive by the switches which control by the PWM method in FLC. Need of the torque load is provided by the ultracapacitor and battery discharging on constant load. By the charging and discharging of the battery, the life of battery is increase and also increases the driving range of vehicle. Though adopting the proposed method, battery life will improve with increase the driving range of vehicle.

\section{REFERENCES}

[1]. Syed Intishab Ali, "Increasing number of vehicles behind pollution", The Times of India, Jun 6, 2014.

[2]. John Connors, "On the Subject of Solar Vehicles and the Benefits of the Technology"1-4244-0632-3/07/\$20.00 @2007 IEEE.

[3]. C. C. Chan, "The state of the art of electric and hybrid vehicles", Proceedings of the IEEE, Vol. 90, No.2, pp. 247-275, 2002

[4]. Alireza Khaligh, and Zhihao Li, "Battery, ultracapacitor, fuel cell, and hybrid energy storage systems for electric, hybrid electric, fuel cell, and plug-in hybrid electric vehicles: State of the art", IEEE Transactions on Vehicular Technology, Vol. 59, No.6, pp. 2806-2814, 2010.

[5]. Jian-Bo Cao and Bing-Gang Cao, "Neural network sliding mode control based on on-line identification for electric vehicle with ultracapacitor battery hybrid power", International Journal of Control, Automation and Systems, Vol. 7, No.3, pp. 409-418, 2009.

[6]. Zhang Jing-Ming, Song Bao-Yu "Fuzzy Logic Approach to Regenerative Braking System" 978-0-7695-3752-8/09 \$25.00 2009 IEEE.

[7]. Xu Jiaqun, Cui Haotian "Regenerative Brake of Brushless DC Motor for Light Electric Vehicle" 978-1-4799-8805-1/15/\$31.00@2015 IEEE.

[8]. Farshid Naseri, Ebrahim Farjah, Teymoor Ghanbari "An Efficient Regenerative Braking System Based on Battery/Supercapacitor for Electric, Hybrid and Plug-In Hybrid Electric Vehicles with BLDC Motor" 0018-9545 (c) 2016 IEEE.

[9]. Akhila M, Prof. Ratnan P "Brushless DC Motor Drive with Regenerative Braking using Adaptive Neuro Based Fuzzy Interface System" 978-1-4673-9939-5/16\$31.00 @ 2016 IEEE.

[10]. N.Pothirasan, Dr.M. Pallikonda Rajasekaran "Regenerative EVehicle Using BLDC Motor" 978-1-5090-3751-3/16/\$31.00 @2016 IEEE.

[11]. O. C. Kivanc, O. Ustun, G. Tosun and R. N. Tuncay "On Regenerative Braking Capability of BLDC Motor" 978-1-5090-34741/16/\$31.00 @2016 IEEE.

[12] C. C. Chan, "The state of the art of electric and hybrid vehicles",Proceedings ofthe IEEE, Vol. 90, No.2, pp. 247-275, 2002.

[13] Georgios Fontaras, "Experimental evaluation of hybrid vehicle fuel economy and pollutant emissions over real-world simulation drivingcycles", Atmospheric environment, Vol. 42, No. 18, pp. 40234035, 2008.

[14] Anupama Singh I, Dr. P.B.Karandikar "Lead-acid Battery for HEV using Fuzzy Controller and Ultracapacitor" 978-1-4673-6658$8116 / \$ 31.00$ @20 16 IEEE 
[15] WANY Feng, ZHANG Tong, WANG Yan-jie, YANG Lin, ZHUO Bin" Steady-State Optimization of Internal Combustion Engine for Hybrid Electric Vehicles" 1-4244-0759-1/06/\$20.OO @2006 IEEE.

[16] Shane Overington "A Novel Model of Internal Combustion Engine for High Efficiency Operation of Hybrid Electric Vehicles and Power Systems" Australasian Universities Power Engineering Conference, AUPEC 2014,

[17] E. Femandez, F Augeri, M. Coello "Implementation of a System Plug-in a Conventional Hybrid Vehicle and Improve EV Condition With an Extra Set of Batteries and Electronic Control" 978-1-5090-12725/16/\$31.00 @2016 IEEE

[18] Li Rui Wei Xuezhe, "Li-ion Battery Management System in a Fuel Cell Vehicle," Computer and Communications, 2004, 5(22), 35-38.

[19] Duo Xiao, Qiuting Wang "The Research of Energy Management Strategy for Fuel Cell Hybrid Vehicle" 978-0-7695-4792-3/12 \$26.00 () 2012 IEEE

[20] J. Bernard, S.Delprat, T. Guerra, and F. Buchi, "Fuel efficient power management strategy for fuel cell hybrid powertrains," Control Engineering Practice, vol.18, no.4, pp.408-417, Apr. 2010.

[21] Rafika Dinnawi, Dima Fares, Riad Chedid*, Sami Karaki, and Rabih A. Jabr "Optimized Energy Management System for Fuel Cell Hybrid Vehicles" 978-1-4799-2337-3/14/\$31.00 @2014 IEEE

[22] S. N. Motapon, L. A. Dessaint, and K. Al-Haddad, "A comparative study of energy management schemes for a fuel-cell hybrid emergency power system of more-electric aircraft," IEEE Trans. Ind. Electron., vol. 61, no. 3, pp. 1320-1334, Mar. 2014.

[23] J. Moreno, M. E. Ortuzar, and J. W. Dixon, "Energy-management system for a hybrid electric vehicle, using ultracapacitors and neural networks," IEEE Trans. Ind. Electron., vol. 53, no. 2, pp. 614-623, Apr. 2006.

[24] A. Ravey, B. Blunier and A. Miraoui, "Control strategies for fuelcell-based hybrid electric vehicles: From offline to online and experimental results," IEEE Trans. Veh. Technol., vol. 61, no. 6, pp. 2452-2458, Jul. 2012.

[25] D. Marra, M. Sorrentino, C. Pianese and B. Iwanschitz, "A neural network estimator of Solid Oxide Fuel Cell performance for on-field diagnostics and prognostics applications," J. Power Sources, vol. 241, pp. 320-329, 2013.

[26] T. P. Murrells, N. R. Passant, G. Thistlethwaite, A. Wagner, Y. Li, T. Bush, J. Norris, C. Walker, R. A. Stewart, I. Tsagatakis, R. Whiting, C. Conolly, S. Okamura, M. Peirce, S. Sneddon, J. Webb, J. Thomas, J. MacCarthy, S. Choudrie, and N. Brophy, "U.K. Emissions of Air Pollutants 1970 to 2008," U.K. Nat. Atmospheric Emissions Inventory (NAEI), 2010. [Online].Available:http://www.airquality.co.uk/reports/at 07/1009030925_2008_Report_final270805.pdf

[27] P. Lailler, F. Zaninotto, S. Nivet, L. Torcheux, J.-F. Sarrau, J.-P. Vaurijoux, and D. Devilliers, "Study of the softening of the positive active-mass in valve-regulated lead-acid batteries for electric-vehicle applications," J. Power Sources, vol. 78, no. 1/2, pp. 204-213, Mar. 1999

[28] Rebecca Carter "Optimizing for Efficiency or Battery Life in a Battery/Supercapacitor Electric Vehicle" 0018-9545/\$31.00 ( 2012 IEEE [29] K. B. Adam and M. Ashari "Design of Bidirectional Converter Using Fuzzy Logic Controller to Optimize Battery Performance in Electric Vehicle" 978-1-4799-7711-6/15/\$31.00 @ 2015 IEEE.

[30] Anupama Singh, Dr. P.B.Karandikar "Lead-acid Battery for HEV using Fuzzy Controller and Ultra-capacitor" 978-1-4673-66588116/\$31.00 @2016 IEEE.

[31]. J. M. Miller, U. Deshpande, T. J. Dougherty, T. Bohn, "Power Electronic Enabled Active Hybrid Energy Storage System and its Economic Viability", APEC, 2009. Twenty-Fourth Annual IEEE, 15- 19 Feb. 2009 Page(s): 190 - 198

[32] Lei Wang, Xiaohu Liu, Hui Li" Power electronics enabled energy management for energy storage with extended cycle life and improved fuel economy in a PHEV" 978-1-4244-5287-3/10/\$26.00 @2010 IEEE

[33] S. S. Williamson, "Electric drive train efficiency analysis based on varied energy storage system usage for plug-in hybrid electric vehicle applications," in Proc. IEEE Power Electronics Specialists Conf. (PESC), 2007, pp. 1515-1520.

[34] P. Denholm and W. Short, An Evaluation of Utility System Impact and Benefits of Optimally Dispatched Plug-in Hybrid ElectricVehicles, National Renewable Energy Laboratory, Tech. Rep., 2006.
[35] K. Schneider, C. Gerkensmeyer, M. Kintner-Meyer, and M. Fletcher, "Impact assessment of plug-in hybrid electric vehicles on pacific northwest distribution systems," in Proc. IEEE Power and Energy Soc. 2008 General Meeting, Pittsburgh, PA, 2008.

[36] Niklas Rotering "Optimal Charge Control of Plug-In Hybrid Electric Vehicles in Deregulated Electricity Markets" 0885-8950/\$26.00 (c) 2010 IEEE

[37] Samba Murthy, Aravind. "Analysis of regenerative braking in electric machines." (2013). 2.3.1

[38] Farshid Naseri "An Efficient Regenerative Braking System Based on Battery/Supercapacitor for Electric, Hybrid and Plug-In Hybrid Electric Vehicles with BLDC Motor" IEEE Transactions on Vehicular Technology ( Volume: 66, Issue: 5, May 2017 )

[39] O. C. Kivanc, O. Ustun, G. Tosun and R. N. Tuncay "On Regenerative Braking Capability of BLDC Motor" 978-1-5090-34741/16/\$31.00 @2016 IEEE

[40] C. H. Chen and M. Y. Cheng "Implementation of a Highly Reliable Hybrid Electric Scooter Drive," IEEE Trans. on Indus. Electron.,vol. 54, no. 5, pp.2462-2473, Oct. 2007.

[49] Cheng-Hu Chenl, Wen-Chun Chi2, and Ming-Yang Cheng2 "Regenerative Braking Control for Light Electric Vehicles" 978-1-45770001-9/11/\$26.00 @2011 IEEE

[41]. Farshid Naseri, Ebrahim Farjah, Teymoor Ghanbari "An Efficient Regenerative Braking System Based on Battery/Supercapacitor for Electric, Hybrid and Plug-In Hybrid Electric Vehicles with BLDC Motor" 0018-9545 (c) 2016 IEEE.

drive." Journal of Electrical Engineering and Technology 9.6 (2014): 1944-1953.

[42] Andrew Adib and Rached Dhaouadi " Modeling and Analysis of a Regenerative Braking System with a Battery-Supercapacitor Energy Storage" 978-1-5090-5454-1/17/\$31.00 @2017 IEEE

[43] H. Hoimoja, D. Vinnikov, M. Lehtla, A. Rosin, J. Zakis, "Survey of loss minimization methods in tram systems," in International Symposium on Power Electronics Electrical Drives Automation and Motion (SPEEDAM), pp.1356-1361, 2010.

[44] B. Hredzak, V.G. Agelidis, G.D. Demetriades, "A Low Complexity Control System for a Hybrid DC Power Source Based on UltracapacitorLead-Acid Battery Configuration," IEEE Transactions on Power Electronics, vol.29, no. 6, pp.2882 - 2891, 2014.

[45] J. Moreno, M. Ortuzar, and J. Dixon, "Energy-management system for a hybrid electric vehicle, using ultracapacitors and neural networks," IEEE Trans. Ind. Electron., vol. 53, no. 2, pp. 614-623, Apr. 2006.

[46] F. Brucchi, F. Giulii Capponi, F. Smargiasse, and P. Santoro, "High efficiency-low cost powertrain for urban electric vehicle," in Proc. 24th Elect. Veh. Symp., Stavanger, Norway, 2009, [CD-ROM].

[47] Rebecca Carter "Optimizing for Efficiency or Battery Life in a Battery/Supercapacitor Electric Vehicle" 0018-9545/\$31.00 () 2012 IEEE [48] B.A. Correa, Y. Zhang, R. Fang, R.A. Dougal, "Driving a synchronous motor so that it emulates a twin-shaft gas turbine engine," 6th IET International Conference on Power Electronics, Machines and Drives, pp.1-6, March 2012

[49] Kaspars Kroics1" Supercapacitor Based Storage System for Efficiency Improvement of Lead-Acid Powered Light Electric Vehicle" 978-1-5090-1798-0/16/\$31.00@2016 IEEE

[50] Anupama Singh, Dr. P.B.Karandikar "Lead-acid Battery for HEV using Fuzzy Controller and Ultracapacitor" 978-1-4673-66588116/\$31.00 @20 16 IEEE

[51] A. A. Abdelgadir and J. Y. Alsawalhi "Energy Management Optimization for an Extended Range Electric Vehicle" 978-1-5090-5454$1 / 17 / \$ 31.00 \_$c 2017 IEEE

[52] R. M. Asif, A. Yousaf, A. U. Rehman, H. M. Ashraf and SU Rehman, "Real Time Extra Economic Dispatch For Renewable Energy Uncertainty Over IEEE Bus Bar" IEEEP New Norizons, vol. 97-100, pp: 9-16, 2018

[53]. Akhila M, Prof. Ratnan P "Brushless DC Motor Drive with Regenerative Braking using Adaptive Neuro Based Fuzzy Interface System" 978-1-4673-9939-5/16\$31.00 @ 2016 IEEE.

[54] M. K. Yoong et al., "Studies of regenerative braking in electric vehicle," Sustainable Utilization and Development in Engineering and Technology (STUDENT), 2010 IEEE Conference on, Petaling Jaya, 2010, pp. 40-45. doi: 10.1109/STUDENT.2010.5686984 
[55] Andrew Adib, Rached Dhaouadi “ Modeling and Analysis of a Regenerative Braking System with a Battery-Supercapacitor Energy Storage" 978-1-5090-5454-1/17/\$31.00 @2017 IEEE

[56] Farshid Naseri "An Efficient Regenerative Braking System Based on Battery/Supercapacitor for Electric, Hybrid and Plug-In Hybrid Electric Vehicles with BLDC Motor" IEEE Transactions on Vehicular Technology.

[57] Tingyou Ming, Weiwen Deng, Jian Wu and Qiao Zhang "A Hierarchical Energy Management Strategy for Battery-Supercapacitor Hybrid Energy Storage System of Electric Vehicle" ITEC Asia-Pacific 20141569952025

[58] Kaspars Kroics1, Viesturs Brazis "Supercapacitor Based Storage System for Efficiency Improvement of Lead-Acid Powered Light Electric Vehicle" 978-1-5090-1798-0/16/\$31.00 @ 2016 IEEE

[59] Parisa Golchoubian and Nasser L. Azad "Real-Time Nonlinear Model Predictive Control of a Battery-Supercapacitor Hybrid Energy Storage System in Electric Vehicles" DOI 10.1109/TVT.2017.2725307, IEEE 